\title{
Farklı Kültürel Uygulamalarla Yetiştirilen Amazon ve Sırma Börülce Çeşitlerinin Verim ve Verim Özellikleri
}

\author{
Gülbahar ÇULHA ${ }^{1}$ \\ *Hatice BOZOĞLU²
${ }^{1}$ Ondokuz Mayıs Üniversitesi, Fen Bilimleri Enstitüsü, Tarla Bitkileri Anabilim Dalı, Samsun ${ }^{2}$ Ondokuz Mayıs Üniversitesi, Ziraat Fakültesi, Tarla Bitkileri Bölümü, Samsun
*Sorumlu yazar e-posta (Corresponding author e-mail): hbozoglu@omu.edu.tr

Öz

Börülce fasulye gibi kullanılabilme özelliğine sahip bir bitkidir ve olumsuz ekolojik şartlardan, özellikle çiçeklenme dönemindeki yüksek sıcaklıklardan ve kuraktan fasulyeden daha az etkilenmektedir. Ayrıca börülcenin zengin vegetatif aksam oluşturabilme yeteneği toprak korumada kullanılmaktadır. Karışık ekime girebilme ve özellikle çeltik ekili alanlarda münavebede kullanılabilme potansiyeli bu bitkinin bölgemizde de şansının olduğunu göstermektedir. Bu nedenlerle bölge şartlarımız için geliştirip 2010 yılında tescil ettirdiğimiz Sırma ve Amazon adlı kuru tane amaçı börülce çeşitlerimizin çiftçilere tanıtılması ve tarımının yaygınlaştırılması için yetiştirme paketinin hazırlanması gerekmektedir. Bu çalışma, iki çeşidin uygun ekim zamanı ve bitki sıklığını ortaya koymak, bu faktörlerin bitkinin verim ve verim özelliklerine etkisini belirlemek üzere planlanmıştır. Denemeler 2 farklı çevrede (konvansiyonel ve organik), 2 çeşit (Amazon, Sırma), 2 ekim zamanı (erken ve geç ekim), 4 farklı sıra arası mesafesi $(30,45,60,75 \mathrm{~cm})$ kullanılarak, 3 tekrarlamalı bölünen bölünmüş parseller deneme deseninde yürütülmüştür. Varyans analizi çevreler ayrı ayrı olacak şekilde yapılmıştır. Konvansiyonel uygulamanın yapıldığı Atakum'da tane verimine zaman, çeşit, sıra arasının, organik tarımın uygulandığı Bafra'da zaman, sıra arası ve zaman x sıra arası interaksiyonunun etkisi olduğu tespit edilmiştir. Erken ekimde verimin her iki çevrede de daha yüksek olduğu, sıra arası daraldıkça bitkide tane veriminin azaldığı tespit edilmiştir.

Anahtar Kelimeler: Börülce, ekim zamanı, sıra arası

\section{Seed Yield and It's Components of Amazon and Sirma Cowpea Varieties that are Grown with Different Cultivatons}

\begin{abstract}
Cowpea which can be used and consumed as bean is a legume plant. It is affected less than beans in the unfavorable ecological conditions and particulary the high temperatures and drought during flowering period. Otherwise it has got the ability to produce rich vegetative material therefore it is used in soil conservation. Cowpea can be sown in intercropping system and particulary at area which is sown rice it can be attended crop rotation. These show that cowpea has got a chance to grown in our region. Amazon and Sırma varieties were developed for our region conditions and were registered in 2010 . The cultivation package of these varieties and should be prepared for the promotion of agriculture and introduced to farmer. This study were planned to determine the appropriate sowing time and plant density of two varieties and the effects of the seed yield and yield characteristics of these factors. The experiments were established on two enviroment (conventional and organic) split split plot desing with 3 replication at two varieties (Amazon, Sırma), two sowing time (early, late), four row space $(30,45,60,75 \mathrm{~cm})$. Analysis of variance was done to separate on the environments. The effect of sowing time, variety, row spacing on the seed yield in Atakum that was made conventional agriculture; sowing time, row spacing and timexrow spacing interaction in Bafra that was made organic agriculture were significant as statistically. The highest seed yield per plant was obtained from early sowing time both enviroments. Narrow row spaces effected seed yield per plant negatively.
\end{abstract}

Keywords: Cowpea, sowing time, row spacing

\section{Giriş}

U" Ikemiz ekolojik koşulları yemeklik baklagil üretimine elverişli olup, 4 tanesinin (nohut, mercimek, bakla, bezelye) anavatanıdır. Yabancı orijinli olan fasulye ve börülce gerek yetiştiriliş gerekse kullanış şekilleri birbirine çok benzeyen baklagillerdir. Fasulye ülkemiz genelinde 
yetiştirilip kullanılan bir bitki olmasına rağmen börülce yetiştiriciliği belirli alanlarda sınırlı kalmıştır. Oysa börülce kurağa ve sıcağa fasulyeden daha dayanıklıdır. Börülce sıcak mevsim baklagillerinden olup, küresel iklim değişikliği nedeniyle gittikçe sıcaklığın arttığı ve suyun tükendiği ülkemizde dikkat çekici bir bitkidir. Börülcenin dünyanın yarı kurak ve tropikal bölgelerinde diğer yemeklik baklagillerden sıcağa ve kurağa tolerans bakımından daha iyi olduğu tespit edilmiştir (Sing et al. 1997; Hall et al. 2003, 2004). Birçok çeltik yetiştiren ülkede toprak ıslahı için münavebe bitkisi olarak da kullanılmaktadır. Toprak istekleri de azdır. Bitki \%7.5-20 ham protein ve $\% 50$ sindirilebilir karbonhidrat içermesi nedeniyle de iyi bir yeşil yemdir. Samanında \%11 protein olup sindirilebilirliği fazladır. Kuru ot ve tane yem olarak da doğrudan yada silaj şeklinde hayvan yemi olarak da kullanılabilir (Gençkan 2003). Bir diğer kullanımı ise yeşil gübre olarak değerlendirilmesidir.

Börülce, ülkemizde 2011 TÜIKK verilerine göre 2032 ha alanda ekilmesine rağmen, dünyada 2012 yılı FAO verilerine göre 11.294.193 ha ekim alanı ile fasulye ve nohuttan sonra dünyada en fazla ekilen baklagildir (FAO 2012). Ülkemizde daha çok Ege, Akdeniz ve Güney Doğu Anadolu'da sınırlı alanlarda yetiştirilmektedir. Karadeniz bölgesinin Sinop, Kastamonu ve Samsun'un Çarşamba, Tekkeköy gibi bölgelerinde az olsa da yetiştiriliciliği yapılmakta yerel pazarlarda çiftçiler tarafından doğrudan pazarlanmaktadır. İklim istekleri mısıra benzer, ancak daha fazla sıcaklık isterken, kurak koşullara ise mısırdan daha dayanıklıdır (Şehirali, 1988). Ülkemizde mısırın en fazla yetiştirildiği yerlerden biri de Samsun'dur. Nitekim bu bilgilerden hareketle yaptığımız çalışmalarda tane veriminin kullanılan genotiplerde dekara 129-169 kg civarında olduğu, ekstrem yıllar hariç Samsun' da sulama yapmadan bile börülce yetiştirmenin mümkün olabileceği sonuçlarına varılmıştır (Gülümser ve ark. 1989; Bozoğlu ve Gülümser 1995). Börülce dünyada, kurağa dayanıklılığı nedeniyle, nemli ve yarı kurak koşullarda ve hatta çeşitlerin büyük çoğunluğu yağışsız koşullarda yetiştirilmekte, dünyanın çeşitli yerlerinde çeltikten sonra su tutma kapasitesi yüksek olan topraklarda kalan su ile yetiştirildiği bildirilmektedir (Şehirali 1988). Börülcenin, önemli bir çeltik üretim alanı olan bölgemizde de, ekim nöbeti sistemine girebilme ve yeni bir ürün kazandırılarak tarımsal ürün çeşitliliğini artırma olasılığı vardır. Bunlardan hareketle bölgede tarımının yaygınlaşabilmesi için ilk adım olarak uygun çeşitlerin geliştirilmesi gerçekleştirilmiş ve 2010 yılında kuru tane amaçlı 2 çeşit (Amazon ve Sırma) tescil ettirilmiştir. Bundan sonra yapılması gereken ise bölge şartları için uygun yetiştirme paketinin hazırlanmasıdır. Bu çalışmanın amacı da bu çeşitlerin yetiştirme paketinin ilk basamakları olan uygun ekim zamanı ve bitki sıklığını belirlemek ve bunların verim ve verim özelliklerine etkisini konvansiyonel ve organik şartlarda kıyaslamaktır.

\section{Materyal ve Yöntem}

Atakum ilçedeki deneme arazisi toprağı, killi yapıda, pH'sı hafif asit, tuzsuz, organik maddesi az, fosforu iyi iken; Bafradaki arazinin toprağı tınlı, hafif alkali, organik maddesi çok fakir, kireçce zengin bir özellik göstermiştir. Deneme yerlerinin iklimsel özelliği Karadeniz ikliminin genel özellikleri olan yazları serin, kışları lık ve yağışııdır. Her iki deneme yerinin aylık sıcaklık değerleri hem uzun yıllar hem de aylık olarak bir birinden farkıı olmamıştır. Yağış miktarı Bafra'da deneme süresince toplam $172 \mathrm{~mm}$ ile uzun yıllar verilerinin altına düşmüş; Atakum ilçede ise bu dönemde $426 \mathrm{~mm}$ ile uzun yıllar verilerinden daha fazla olmuştur.

$\mathrm{Bu}$ projenin materyali, kuru tane amaçlı kullanıma uygun tarafımızca geliştirilmiş Amazon ve Sırma çeşitleridir. TTSM çeşit özellik belgesine göre Sırma bodur, dik gelişen bitki tipinde, sarılma eğilimi orta, tane şekli eşkenar dörtgen, tane hilum halka rengi sarımsı kahve, bakla olgunlaşma süresi orta; Amazon bodur, dik gelişen bitki tipinde, sarılma eğilimi hafif, tane şekli böbrek, hilum halka rengi siyah, bakla olgunlaşma süresi orta olan çeşitlerdir.

Denemeler 2013 yılında biri Samsun ili Atakum ilçesinde bulunan Ondokuz Mayıs Üniversitesi (OMÜ) Ziraat Fakültesi deneme arazisinde, diğeri ise Bafra ilçesinde üniversitemizin Tarımsal Uygulama ve Araştırma arazisinde yürütülmüştür. Atakum ilçede yer alan arazide daha önceki yıllarda börülce yetiştirilmiş olmasına rağmen Bafra arazisinde hiç börülce yetiştirilmediği gibi bu alan organik tarım için ayrıımış alandır. Atakum ilçedeki deneme konvensiyonel, Bafradaki ise organik tarım yöntemi ile yetiştirilmiştir.

Börülcenin vegetasyon süresinin uzun olması ve bölgemizde bahar yağışları nedeniyle arazi hazırlığının zorluğu dikkate alındığında ekimde gecikmeler olabilmektedir. Bu nedenle 
bu farklııkların bitki verimi ve kalitesine nasıl etki ettiğini belirlemek için bir ay aralıkla biri erken diğeri geç olmak üzere (nisan sonu, mayıs sonu) 2 ekim zamanı seçilmiştir. Sıra üzeri mesafesi $(15 \mathrm{~cm})$ eşit olmak üzere 4 farklı sıra arası mesafesi $(30,45,60,75 \mathrm{~cm})$ dikkate alınmıştır. Bu mesafeler kullanılarak yapılan ekimlerle sırasıyla metre karede 22.2, 14.8, $11.1,8.9$ bitki yer almıştır. Denemeler bölünen bölünmüş parseller deneme deseninde 3 tekrarlamalı olarak yürütülmüştür. Ana parsellere ekim zamanı, alt parsellere çeşitler ve alt alt parsellere sıra arası mesafeleri getirilmiştir. Parselde 5 sıra olacak şekilde ekimler, Atakum'da 24 nisan, 22 mayıs; Bafra da ise 25 nisan, 24 mayıs tarihlerinde yapılmıştır. Denemelerde gerekli görüldüğünde sulama ve çapalama işlemi, Atakum ilçede $4 \mathrm{~kg}$ saf azot hesabıyla gübreleme yapılmış; Bafra da gübreleme ve ilaçlama yapılmamıştır.

Varyans analizleri SPSS-13 paket program yardımıyla her iki çevrede ayrı ayrı olacak şekilde bölünen bölünmüş parseller deneme desenine göre yapılmış ve Duncan çoklu karşılaştırma testi kullanıımıştır. Çevrelerin kıyaslaması ise t- testi ile gerçekleştirilmiştir.

\section{Bulgular ve Tartışma}

Baklagiller konusunda çalışan araştırıcıların hedeflerinden biri baklagil üretimini arttırabilmek için bölgesel şartlara uygun ve tüketicinin talepleri doğrultusunda yeni çeşitler geliştirmektir. $\mathrm{Bu}$ amaçla mercimek, nohut ve fasulye konusunda ülkemizde oldukça önemli yol kat edilmiştir. Son yıllarda börülce, bezelye, bakla gibi diğer baklagillerle çeşitliliği artırmak istenmektedir. Bu çalışma ile bölge şartlarımız için geliştirdiğimiz 2 adet kuru tane amaçlı börülce çeşidi için uygun yetiştirme tekniği belirlemek hedeflemiştir.

Biri konvansiyonel diğeri organik olmak üzere iki çevrede yetiştirilen Amazon ve Sırma çeşitlerinin bazı agronomik özelliklerine ait ortalamaları Çizelge 1 'de verilmiştir. Konvansiyonel tarım şeklinin uygulandığı Atakum'da bitki boyuna çeşit $(P<0.05)$ ve çeşit $x$ zaman interaksiyonu $(P<0.01)$; bakla sayısına çeşit $(P<0.01)$ ve ekim zamanı $(P<0.01)$; baklada tane sayısına sıra arası $(P<0.05)$; bitkide tane verimine çeşit $(P<0.01)$, zaman ve sıra arası faktörlerinin $(P<0.05)$ istatistiki etkisi olduğu tespit edilmiştir. Organik yetiştiriciliğin yapıldığı Bafra'da ise bitki boyuna çeşit $(P<0.05)$, sıra arası $(P<0.01)$; bakla sayısına zaman ve sıra arası $(P<0.01)$, tane verimine zaman, sıra arası $(P<0.01)$ ve zaman $x$ sıra arası interaksiyonunun $(P<0.05)$ istatistiki etkilerinin olduğu belirlenmiştir.

Börülce tek yıllık otsu bir bitki olup büyüme habitusu dik formdan tırmanıcıya kadar değişiklik gösterir, büyüme tipi sınırlı ve sınırsız olabilmektedir (Bozoğlu ve Pekşen 2009). Denemede kullanılan çeşitlerin büyüme tipi indeterminattır. $\mathrm{Bu}$ da bitkinin yetiştirme koşullarına bağlı olarak hem boyunu hem de hasat süresini etkilemektedir. Samsun ilk ve son baharı bol yağış alan bir ildir. Bu nedenlerle yazlık ürünlerin ekim zamanında da hasat zamanında da yağış fazlalığı nedeniyle problem yaşanmaktadır. Bu durum dikkate alınarak bu denemede bir ay aralıkla iki ekim zamanı denenmiştir. Ceylan ve Sepetoğlu (1983) Bornova ekolojisinde vejetasyon devresi uzunluğunun genel olarak ekim zamanı geciktikçe kısaldığı, tane veriminin 32.9-126.5 $\mathrm{kg} / \mathrm{da}$ arasında değiştiği, özellikle bitkide bakla sayısının ekim zamanı geciktikçe belirgin bir şekilde azalma gösterdiği sonucuna varmışlardır. Ünlü (2004), Isparta koşullarında 15 mayısta başlayarak 15 'er gün aralıklarla 4 ekim zamanının denediği çalışmasında ekim geciktikçe büyüme süresinin tamamlanamadığını ve en yüksek tane verimini 30 mayıs ekiminden aldığını bildirmiştir. Akdağ ve ark. (1998), 8 börülce çeşidi ve 4 ekim zamanı kullanarak yürüttükleri çalışmada, tane veriminin ekim zamanına göre 158.86-200.85 kg/da arasında değiştiğini gözlemlemişlerdir. Bizim çalışmamızda hasat süresi Atakum şartlarında ekim zamanı sıralamasıyla ortalama 150 ve 130; Bafra şartlarında ise 144 ve 126 gün sürmüştür. Her iki çevrede incelenen özelliklerden bitkide bakla sayısı ile tane verimi zamandan etkilenmiştir. Atakum ilçede bakla sayısı erken ekimde 18.06 adet iken geçte 13.14 adete; tane verimi ise erken ekimde 23.46, geçte $19.53 \mathrm{~g}$; Bafra koşullarında ise erken ekimde bakla sayısı 14.58 , geçte 8.52 adet; tane verimi ise sırasıyla 16.74 ile $15.28 \mathrm{~g} / \mathrm{bitki}$ olmuştur. Organik koşullarda yetiştiricilikte her iki özellikte de önemli azalma tespit edilmiştir. Çevrelerin kıyaslanması için yapılan $\mathrm{t}$ testi sonucu $\left(\mathrm{t}=3.328^{* \star}\right)$ bu azalışın istatistiki olarak çok önemli olduğu belirlenmiştir. Ancak bu azalmanın nedenin tamamı organik yetiştiricilikten değil, bir kısmının da alanda hiç börülce ve diğer baklagillerin uzun yıllardan beri yetiştirilmemiş olması nedeniyle azot fiksasyonunun azlığı ve kısıtlı imkanlar nedeniyle yeterince sulama yapılamamasından olduğu düşünülmektedir. 


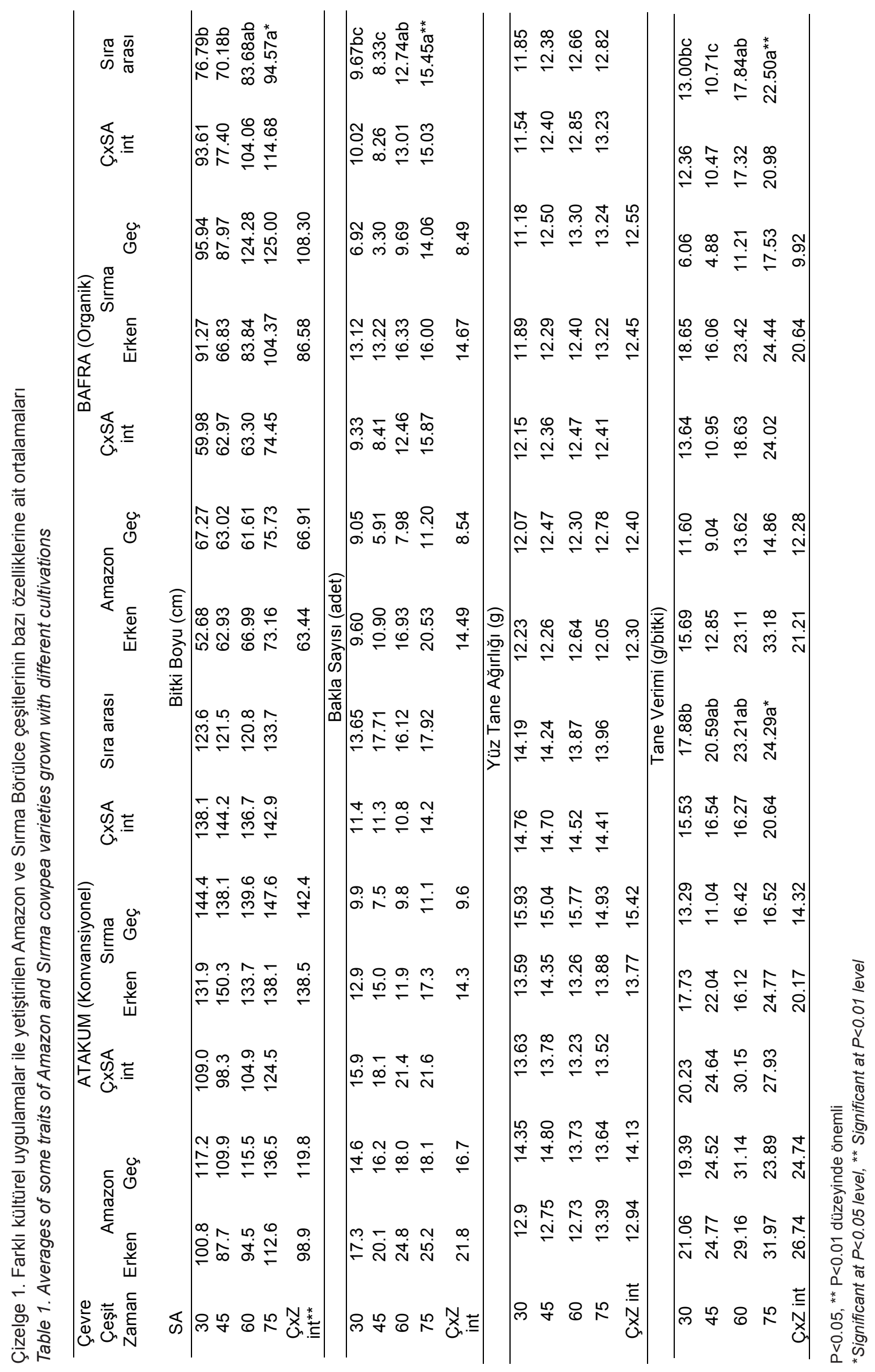




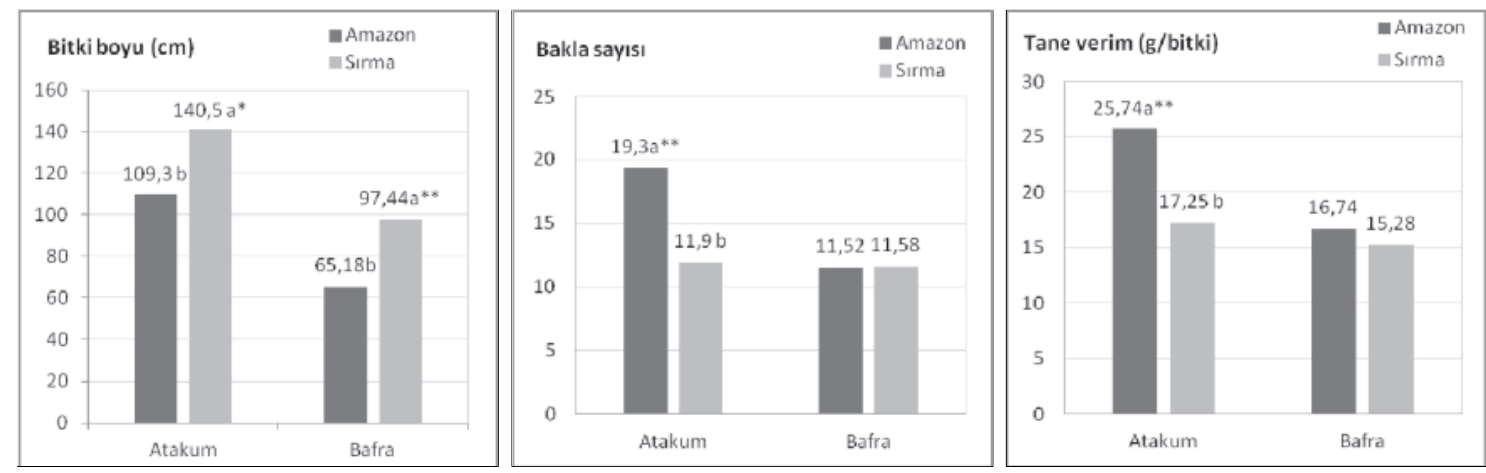

Şekil 1. Börülce çeşitlerinin farklı çevre şartlarında bazı özelliklerindeki değişim

Figure 1. Variations between some traits of cowpea varieties in different enviroments

Çeşitlerin değişen çevrelerdeki bazı özelliklerine ait değişimler Şekil 1'de verilmiştir. Çevre şartlarından etkilenen bitki boyu, bakla sayısı ve tane veriminin her iki çeşitte de Atakum şartlarında daha yüksek olduğu tespit edilmiştir. Bu farklılığın gübrelemeden ziyade sulama-yağış ve özellikle azot fiksasyonundan kaynaklandığını düşünmekteyiz.

Amazon çeşidi karagöbek, Sırma ise sarı göbek tane tipinde ve büyüme şekilleri sırık-çalı formu olup birbirine benzerdir (Bozoğlu ve Pekşen 2009). Bu çalışmada konvansiyonel yetiştiricilikte çeşitlerin bitki boyu, bakla sayısı ve tane verimi; organik yetiştiricilikte ise sadece bitki boyunda istatistiki farklılıklarının olduğu tespit edilmiştir. Her iki çevrede de Sırma çeşidinin daha uzun boylu olduğu görülmüştür. Şekil 1'den de görülebileceği gibi bitki boyu gübreleme ve sulamanın daha iyi yapıldığı konvansiyonel yetiştiricilikte yüksek olmuş ve yapılan t testi $\left(\mathrm{t}=6.97^{* *}\right)$ sonucu bu farklılık istatistiksel olarak önemli bulunmuştur. Benzer durum bakla sayısı $\left(\mathrm{t}=3.32^{* *}\right)$, yüz tane ağırlığı $\left(\mathrm{t}=5.16^{* *}\right)$ ve tane veriminde de $\left(\mathrm{t}=3.19^{* *}\right)$ de tespit edilmiştir

Denemelerde 4 farklı sıra arası mesafe (30, $45,60,75 \mathrm{~cm}$ ) uygulanmıştır. Sıra üzeri mesafesi sabit tutulup bu sıklıklarda dönüme sırası ile 22.222, 14.813, 11.111, 8.888 adet bitki olacağı hesaplanmıştır. Konvansiyonel yetiştiricilikte sıra arasının değişimi sadece tane verimini etkilerken; organik yetiştiricilikte bitki boyu, bakla sayısı ve tane veriminin etkilendiği görülmüştür (Çizelge 1). Atakum şartlarında bitki başına tane verimi değişen sıra aralıklarında 17.88 ile $24.29 \mathrm{~g}$ olmuş ve en yüksek tane verimi $75 \mathrm{~cm}$ sıra aralığından elde edilmiş ancak 60 ve $45 \mathrm{~cm}$ aralıklar da aynı istatistiki grupta yer almıştır. Verimler, dekarda olması gereken bitki sayıları dikkate alınarak hesaplandığında en yüksek verim 397.3 kg/da ile $30 \mathrm{~cm}$ sıklıktan elde edilmektedir. Bafra şartlarında ise sıra arası arttıkça bitki boyunun, bitkide bakla sayısı ve tane veriminin arttığı tespit edilmiştir. Bitki boyu $70.18-94.57 \mathrm{~cm}$, bakla sayısı 8.83-15.45 adet, tane verimi 10.71$22.50 \mathrm{~g}$ arasında değerler almıştır (Çizelge 1). Yine dekardaki olması gereken bitki üzerinden hesap yapıldığında dekara tane verimi 158.5288.9 kg aralığında değişmekte ve en yüksek verim $30 \mathrm{~cm}$ sıra arası mesafeden alınmaktadır. Mali ve Mali (1991), Hindistan'da yağışlı sezonlarda 3 farklı çeşitle yaptıkları çalışmada, en yüksek tane verimini $30 \mathrm{~cm}$ sıra arası mesafeden elde edildiğini tespit etmişlerdir. Özturan (2003) Samsun şartlarında, 25-50-75$100 \mathrm{~cm}$ sıra arası mesafede yürüttüğü denemede sıra aralıklarının tane verimine istatistiki etkisi olduğu belirlenmiş ve en yüksek tane verimi $(273.1 \mathrm{~kg} / \mathrm{da}) 25 \mathrm{~cm}$ sıra aralığından almıştır. Bahçeci ve Engin (1989), Çukurova koşullarında iki börülce çeşidinde en uygun ekim sıklığını saptamak amacıyla yaptıkları çalışmada, en yüksek tane veriminin $30 \mathrm{~cm}$ sıra arası mesafesinden elde edildiğini bildirmiştir. Akdağ (1995), Tokat şartlarında yürüttüğü denemede 4 börülce çeşidini 4 sıra aralığında $(30,50,70$ ve $90 \mathrm{~cm})$ ekmiş sıra aralığının genişlemesi ile bitki başına bakla sayısı, tane sayısı, tane verimi ve biyolojik verimi azalışını istatistiki olarak önemli bulmuştur. Erman ve Çığ (2009) Van şartlarında farklı bitki sıklığında (20, 40, 60 ve 80 bitki $/ \mathrm{m}^{2}$ ) iki farklı börülce populasyonunda (Evci ve Oba) bitkide tane verimi, bitkide bakla ve tane sayısı, bitkide dal sayısı ve 100 tane ağırlığı ile ilgili en yüksek değerler 20 bitki $/ \mathrm{m}^{2}$ uygulamasından elde edildiğini bildirmiştir. Sert (2011) Hatay ili ekolojik şartlarında 3 börülce genotipini (Sarıgöbek,Karnıkara ve Samandağ) 3 sıra aralığı $(50,60$ ve $70 \mathrm{~cm})$ ve 3 sıra üzeri $(10,15$ ve $20 \mathrm{~cm}$ ) mesafelerinde denemeye almıştır. 
Araştırma sonuçlarına göre tane verimi bakımından genotipler, sıra arası ve sıra üzeri mesafeleri arasında istatistiki olarak önemli farklılıklar tespit edilmiştir. Genotiplerin ve sıra üzeri mesafelerinin ortalaması olarak en yüksek tane verimi $110.42 \mathrm{~kg} / \mathrm{da}$ ile $50 \mathrm{~cm}$ sıra aralığında tespit edilmiştir.

\section{Sonuç}

Börülcenin vegetasyon periyodunun uzunluğu ve sıcaklık isteğinin yüksekliği dikkate alındığında tane veriminin de erken ekimde daha yüksek olmasından dolayı bölge şartlarında mayıs ayı başlarında yapılmasını önermekteyiz. Denemede kullanılan çeşitlerin tane karakterleri birbirinden farklıdır. Bu nedenle tüketici talebi dikkate alınarak çeşit seçilmelidir. Bitki başına verimler dikkate alındığında 45, 60 ve $75 \mathrm{~cm}$ sıra aralığı istatistiki olarak $30 \mathrm{~cm}$ 'den farklılık gösterirken dekarda bitki sayısının fazlalığına bağlı olarak sıra arası daraldıkça verimin artması söz konusudur. Ancak bu teorik hesaplama yanı sıra bitkinin gelişme seyri ve özellikle bakım işlemleri de düşünüldüğünde 30 $\mathrm{cm}$ mesafenin uygun olmadığı, $60 \mathrm{~cm}$ sıra aralığını da geçmeden ekim yapılmasını önermekteyiz. Bu çalışmada çevre olarak konvansiyonel ve organik yetiştiricilik şartları denenmiş, bölgemizin en önemli çeltik yetiştirme alanı olan Bafra'da çeltik yetiştiriciliği yapılan alanda deneme kurulmuştur. Deneme ortalaması olarak konvansiyonel yetiştiricilik yapılan çevreye nazaran bitki başına tane veriminde $\% 25$ azalış görülmüş ve bu azalışın istatistiki olarak önemli olduğu tespit edilmiştir. Ancak bu farklılığın sadece gübrelemeden değil yeterince sulama yapılamaması ve hiç börülce yetiştirilmemiş olması nedeniyle aktif bakteri ırkının olmaması gibi nedenlerden de kaynaklanabileceğini düşünmekteyiz. Değişen uygulamalarda tane verimin 158-288 kg/da arasında değiştiği görülmüştür. Bu veriler başka çevrelerde yürütülen birçok deneme verilerinden daha yüksektir.

Börülce dünya literatürlerinde de belirtildiği gibi çeltik alanlarında toprak ıslahı için ekim nöbetine giren bir bitkidir. Bu çalışma sonuçları da bölge şartlarında yetiştirilme imkanı olduğunu, ekim nöbeti çalışmalarına katılabileceğini göstermektedir.

\section{Kaynaklar}

Akdağ C., 1995. Sıra aralıklarının Tokat-Kazova şartlarında börülce (Vigna sinensis (L.) Savi)'nin verim ve verim unsurlarına etkileri. Gaziosmanpaşa Üni. Ziraat Fak. Dergisi, 12(1): 141-146
Akdağ C., Gül K. ve Düzdemir O., 1998. Börülcenin (Vigna sinensis (L.) ENDL) Tokat-Kazova şartlarına adaptasyonu ve uygun ekim zamanının belirlenmesi. Gaziosmanpaşa Üni., Ziraat Fak. Dergisi, 343-357

Bahçeci B. ve Engin M., 1989. İki börülce bitkisinde farklı ekim sıklığının bazı bitkisel ve tarımsal özelliklere etkisi üzerinde bir araştırma. Çukurova Üni. Fen Bilimleri Enstitüsü, Fen ve Mühendislik Bilimleri Dergisi, 3(3): 21-28

Bozoğlu H. ve Gülümser A., 1995. Samsun ilinde börülce yetiştirilebilme olanakları. Karadeniz Bölgesi Tarımının Geliştirilme-sinde Yeni Teknikler Kongresi, 10-11 Ocak 1995, Samsun, Bildiri Kitabı: 349-353

Bozoğlu H. ve Pekşen E., 2009. Kuru tane amaçlı tescile aday börülce (Vigna unguiculata L.) hatlarının bazı özellikleri. Türkiye VIII. Tarla Bitkileri Kongresi, 19-22 Ekim 2009, Hatay, s:343-346

Ceylan A. ve Sepetoğlu H., 1983. Börülcede (Vigna sinensis Endl.) çeşit-ekim zamanı üzerine araştırma. Ege Üni. Ziraat Fak. Dergisi, 20(1): $25-40$

Erman M. ve Çığ F., 2009. Farklı bitki sıklığı uygulamalarının börülce (Vigna unguiculata L.) Walp.)'de verim ve verim öğelerine etkisi. Türkiye VIII. Tarla Bitkileri Kongresi-Poster Bildiriler, 669-672

FAO 2012. www.fao.org

Gülümser A., Tosun F. ve Bozoğlu H., 1989. Samsun ekolojik koşullarında börülce yetiştirilmesi üzerinde araştırmalar. Ondokuz Mayıs Üni. Ziraat Fak. Dergisi 4(1-2): 49-65

Hall A.E., 2004. Breeding for adaptation to drought and heat in cowpea. European Journal of Agronomy, 21(4): 447-454

Hall A.E., Cisse N., Thiaw S., Elawad H.O.A., Ehlers J., Ismail A.M., Fery R.L., Roberts A., Kitch L.W., Murdock K.L., Boukar O., Phillips R.D. and McWatters K.H., 2003. Development of cowpea cultivars and germplasm by the bean/cowpea crsp. research highlights of the bean/cowpea collaborative research support program, 1981 - 2002. Field Crops Research, 82(2-3): 103-134

Mali O.P. and Mali A.L., 1991. Responce of promising cowpea (Vigna unguiculata L.) genotypes to row spacing and phosphate levels. Indian J. Agricultural Science, 61(9): 672-673

Özturan Y., 2003. Börülce (Vigna unguiculata (L.) Walp.)'de bitki sıklığı ve azotlu gübrelemenin verim ve verim öğelerine etkisi. Ziraat Fak. Dergisi, 19(3): 41-49 
Çulha and Bozoğlu "Seed Yield and It's Components of Amazon and Sırma Cowpea Varieties that are Grown with Different Cultivatons"

Şehirali S., 1988. Yemeklik Tane Baklagiller IV.Börülce. Gıda-Tarım ve Hayvancılık Bakanlığı, Ziraat İşleri Genel Müdürlüğü Yayınları, Ankara

Sert H., 2011. Hatay İli Ekolojik Şartlarında Börülce (Vigna sinensis (L.) Savi) Çeşitlerinin Tane Verimi ve Bazı Tarımsal Özellikleri Üzerine Farklı Bitki Sıklıklarının Etkileri. Yüksek Lisans Tezi, Selçuk Üniv. Fen Bilimleri Enstitüsü, 45s
Sing B.B., Chambliss O.L. and Sharma B., 1997 Recent advances in cowpea breeding advances in cowpea research. IITA, JIRCAS.

Ünlü H., 2004. Börülce (Vigna unguiculata (L.) Walp.) çesitlerinde farklı ekim zamanlarının sulu ve kurak koşullarda verim ve kalite özelliklerine etkisi. Yüksek Lisans Tezi, Süleyman Demirel Üni. Fen Bilimleri Enstitüsü, Isparta 